\title{
Current situation of nitric pollution of irrigation water in the irrigated perimeter of F'Kirina (Algeria): extent and content
}

\author{
Sihem Fellah ${ }^{1,2, *}$, Ghania Atmani-Merabet ${ }^{1,3}$ \& Abdelkader Khiari² \\ ${ }^{1}$ Departments of Dental Surgery, Salah Boubnider University Constantine 3, Algeria \\ ${ }^{2}$ University Benmhidi Larbi of Oum El Bouaghi, Faculty of Exact Sciences and Sciences of Nature and Life. Department of Science \\ of Nature and Life, Algeria \\ ${ }^{3}$ Laboratory of Pharmacology and Toxicology, Mentouri University Constantine 1, Algeria \\ ${ }^{*}$ Corresponding author, email: fellah_sihem@yahoo.fr.
}

\begin{abstract}
The plain of F'Kirina belongs to the sub-watershed of Garaet Tarf(Algeria). Its area is of the order of $760 \mathrm{~km}^{2}$. The intensification of agriculture in this region leads to a significant use of phytosanitary products. The examination of the nitrate results on a low level of the measurements carried out on all the points of the plain of F'Kirina shows an area with a high concentration: near the salt lake Gareat Taref, the concentration of nitrates in the waters of irrigations are between 40 and $65 \mathrm{mg} / \mathrm{l}$. In addition, in this zone, the water table is shallow, making the zone saturated with nitrate far exceeding the recommended standard, this mainly due to the presence of salt water. In the rest of the plain, the nitrate contents of the water remain in the standards of potability; they do not exceed $10 \mathrm{mg} / \mathrm{l}$. These results confirm the impact of agricultural intensification in the degradation of the groundwater quality of the F'Kirina region.
\end{abstract}

KEY WORDS Agricultural pollution; Groundwater; Physicochemical parameters; Nitrates.

Received 26.11.2019; accepted 15.02.2020; published online 29.05.2020

\section{INTRODUCTION}

In recent years, the protection and conservation of natural environments, particularly water quality, has become a major concern and a major goal in development programs. Indeed, the increasing scarcity of national water resources and their deteriorating quality has led our country, in parallel with sustained efforts in water resources development and management, to pay special attention to the economy of the country and, mainly, in irrigation and control of all types of pollution.

Nitrogen is the most problematic element in agriculture. The highly soluble and mobile nitrates in the soil solution easily leach to the groundwater and thus constitute a potential source of pollution of the water table by nitrates (Soudi, 1995; Zoller, 1994).

The intensive cultivation of agricultural land in irrigated areas has led, in recent years, to the problem of pollution of groundwater resources by the nitrate ion. Concerns about this pollutant then increased, not only because of economic losses to the farmer or consequences on the health of the population, but also because of the complexity of the problem. Indeed, nitrates have a peculiarity that other pollutants do not have. They can be found in soil and water either as a result of fertilizer input, or as a consequence of natural biochemical processes that are closely dependent on regional pedoclimatic and ecological conditions.

In the irrigated perimeters of F'Kirina (Algeria), 
diffuse nitric pollution of groundwater decreases the potential of water resources of good quality, generates a health risk for the rural population and jeopardizes the socio-economic development of the country. Its mastery requires sufficient knowledge of the causes and mechanisms responsible for this pollution.

The deterioration of the quality of water resources constitutes a threat as important as that linked to the quantitative imbalance. Pollution continues to reduce the global balance of water resources and creates a risk for human health especially when it comes to the consumption of well water in rural areas where the majority of the population gets their supplies directly from the water aquifer (Id Ahmad, 1998).

\section{MATERIAL AND METHODS}

The chemical composition of water plays an important role in the determination of its quality, thus the possibility of its use for the supply of drinking water or other uses such as for irrigation.

The interpretation of the chemical composition of the waters makes it possible to compare the waters between them to explain the supply of the aquifers and its flow.

The physicochemical study of the groundwater of the F'Kirina plain is based on the sampling campaign conducted in 2015 . The irrigation water samples were collected and transported to the laboratory within 24 hours following the sampling and analyzed to determine their physicochemical characteristics.

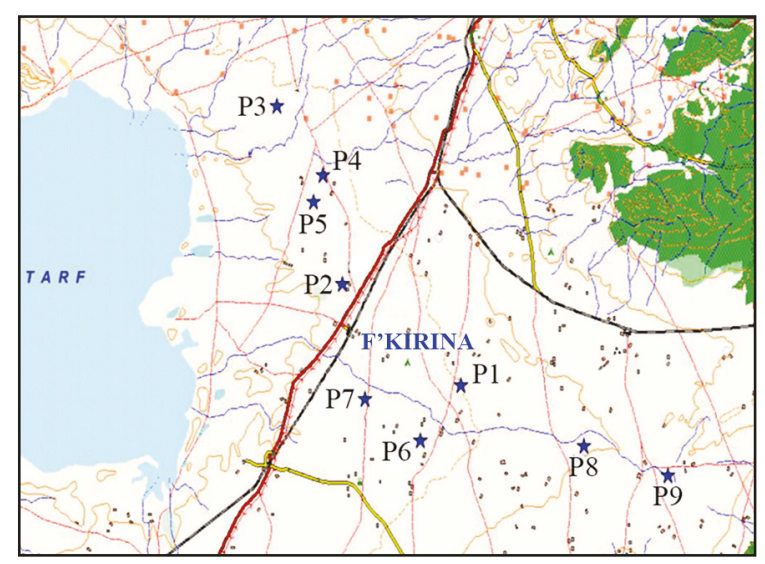

Figure 1. Geographical location of the sampling water points (F'Kirina, Algeria).

\section{Sampling procedure}

The purpose of the sampling is to collect a portion of water whose volume $(500 \mathrm{~mL})$ is small enough to be transported easily but sufficiently representative for its analysis to demonstrate the characteristics of the entire equipment from which the sample is drawn. The sample must be handled in such a way that its composition is not altered during transport and all possible precautions must be taken to eliminate contamination or a change in sample composition caused by temperature or inadequate handling.

For sampling, at the beginning, the cold water must be allowed to run for 5 minutes at high flow before taking a sample to ensure that the water drawn is representative of that flowing through the distribution system. Then fill and rinse the bottle 3 times before proceeding with the actual sampling. When sampling, do not stick the neck of the bottle to the faucet to avoid contamination by metals. Fill the bottle to the brim to avoid the presence of air; and close the bottle tightly with the stopper.

The chemical analyzes were carried out at the water chemistry laboratory of ANRH in Constantine.

\section{Location of water points}

Nine operating wells exist in the study area (P1P9). We had access only to water withdrawals, but not to piezometry, because there was no access to drilling. The spatial distribution of the wells and the source is shown in figure 1 .

\section{Statistical analysis of hydrochemical data}

The statistical study of the data is essential to know the existing relations between the variables and the individuals as well as their spatial and temporal evolution. To achieve these goals, we opted for two studies: a) the first is preliminary, it concerns the elementary statistical study of the variables; b) the second one is more advanced, it is the Analysis in Principal Components (ACP) and treats the existing relations between the variables and the individuals as well as their spatio-temporal evolution. 


\section{RESULTS AND DISCUSSION}

\section{Elemental analysis}

Descriptive statistical analysis of the data is presented in Table 1. This table shows that:

- the average conductivity of the water is 1.59 $\mathrm{ms} / \mathrm{cm}$, but it shows a large difference between the different values with a standard deviation of 0.85 $\mathrm{ms} / \mathrm{cm}$ and a range (maximum - minimum) of 2.4 $\mathrm{ms} / \mathrm{cm}$;

- the temperature of the water is mainly low $\left(<20^{\circ}\right.$ $\mathrm{C}$ ), averaging $17.7^{\circ} \mathrm{C}$, this amounts to the fact that the boreholes capture deep aquifers, where the waters are not very influenced by the climatic changes; - the $\mathrm{pH}$ is neutral to basic in all waters, indicating a release of $\mathrm{CO} 2$ or a combination of the latter with $\mathrm{Ca} 2+$ to form calcite. The range of $\mathrm{pH}$ changes is between 6.3 and 8.4 .

The chemical elements have varying concentrations and can be divided into two groups:

- Low to medium concentration group: the element with the lowest concentrations is magnesium $(\mathrm{Mg} 2+)$ with an average of $41.44 \mathrm{mg} / \mathrm{l}$ followed by sodium and potassium $(\mathrm{Na}++, \mathrm{K}+)$ with an average concentration of $56.04 \mathrm{mg} / \mathrm{l}$, and lastly (NO3) with an average of $38.29 \mathrm{mg} / 1$.

- High concentration group: it starts with sulfates (SO42-) with an average of $189.29 \mathrm{mg}$.

To find out the significant relationships, we used the Mangin formula (Mangin, 1974) to determine the threshold of good correlations $\mathrm{R}$ (relation $\mathrm{N}^{\circ} 1$ ):

$$
R^{2}=\frac{2}{\sqrt{n-3}}
$$

After calculation, we got $\mathrm{R}=0.67$, which implies that all correlations above 0.67 are good relationships.

These correlations show that the variations of the dissolved ionic charges are wholly or partly related to variations in the contents of these different ions. This also indicates that these different parameters tend to evolve concomitantly, by concentration under the effect of lithology.

They are shown in bold in the correlation table. This matrix shows:

- a good relationship between $\mathrm{Na}+$ and $\mathrm{Cl}$-, indicating that the origin of these two ions is halite $(\mathrm{NaCl})$ - a strong relationship between $\mathrm{Mg}++$ and $\mathrm{Cl}$ - indicating that the origin of these two ions is $\mathrm{MgCl}$ (magnesium chloride).

- a strong relationship between $\mathrm{Mg}++$ and SO42indicating that the origin of these two ions is MgSO4 (magnesium sulphate: anhydrous salt). - a good relationship between $\mathrm{Ca}++$ and $\mathrm{SO} 42-$ indicating that the origin of these two ions is CaSO4(Gypsum).

- a good relationship between $\mathrm{Ca}$ and $\mathrm{Cl}$ indicating that the origin of these two ions is $\mathrm{CaCl}$ - (calcium chloride).

\begin{tabular}{|lllllllll|}
\hline Variable & Comments & $\begin{array}{l}\text { Comments } \\
\text { with } \\
\text { missing data }\end{array}$ & $\begin{array}{l}\text { Comments } \\
\text { without } \\
\text { missing data }\end{array}$ & Minimum & Maximum & Moyenne & Extented & $\begin{array}{l}\text { Ecart- } \\
\text { type }\end{array}$ \\
\hline TAC & 9 & 0 & 9 & 1.64 & 4.50 & 3.54 & 2.86 & 0.91 \\
$\mathbf{H C O}_{3}$ & 9 & 0 & 9 & 100.04 & 274.50 & 202.50 & 174.46 & 47.96 \\
$\mathbf{C l}$ & 9 & 0 & 9 & 60.35 & 495.25 & 197.26 & 434.9 & 140.63 \\
$\mathbf{S O}_{4}$ & 9 & 0 & 9 & 14.00 & 380.00 & 150.44 & 365.00 & 133.27 \\
$\mathbf{N O}$ & 9 & 0 & 9 & 3.70 & 65.00 & 37.44 & 61.30 & 21.72 \\
$\mathbf{D H T}$ & 9 & 0 & 9 & 6.00 & 20.60 & 10.29 & 14.60 & 5.17 \\
$\mathbf{C a}$ & 9 & 0 & 9 & 120.24 & 244.49 & 153.23 & 124.25 & 44.25 \\
$\mathbf{M g}$ & 9 & 0 & 9 & 10.00 & 126.95 & 34.75 & 115.19 & 37.54 \\
$\mathbf{N a}$ & 9 & 0 & 9 & 20.50 & 106.95 & 47.99 & 86.45 & 30.36 \\
$\mathbf{K}$ & 9 & 0 & 9 & 0.06 & 0.83 & 0.32 & 0.77 & 0.31 \\
$\mathbf{C E}$ & 9 & 0 & 9 & 0.77 & 3.17 & 1.40 & 2.40 & 0.63 \\
$\mathbf{p H}$ & 9 & 0 & 9 & 6.30 & 8.40 & 7.01 & 2.10 & 0.91 \\
\hline
\end{tabular}




\begin{tabular}{|lllllllllllll|}
\hline TAC & 1 & 0.88 & -0.88 & -0.64 & -0.38 & -0.84 & -0.63 & -0.88 & -0.57 & -0.52 & -0.86 & -0.68 \\
HCO & 0.88 & 1 & -0.84 & -0.42 & -0.39 & -0.72 & -0.50 & -0.82 & -0.38 & -0.34 & -0.77 & -0.68 \\
$\mathbf{C l}$ & -0.88 & -0.84 & 1 & 0.79 & 0.34 & 0.95 & 0.81 & 0.94 & 0.74 & 0.76 & 0.98 & 0.74 \\
$\mathbf{S O}_{4}$ & -0.64 & -0.42 & 0.79 & 1 & 0.07 & 0.92 & 0.83 & 0.84 & 0.83 & 0.86 & 0.88 & 0.61 \\
$\mathbf{N O}_{3}$ & -0.38 & -0.39 & 0.34 & 0.07 & 1 & 0.27 & 0.38 & 0.17 & 0.02 & 0.08 & 0.29 & 0.19 \\
$\mathbf{D H T}$ & -0.84 & -0.72 & 0.95 & 0.92 & 0.27 & 1 & 0.89 & 0.94 & 0.76 & 0.80 & 0.98 & 0.68 \\
$\mathbf{C a}$ & -0.63 & -0.50 & 0.81 & 0.83 & 0.38 & 0.89 & 1 & 0.70 & 0.58 & 0.74 & 0.83 & 0.36 \\
$\mathbf{M g}$ & -0.88 & -0.82 & 0.94 & 0.84 & 0.17 & 0.94 & 0.70 & 1 & 0.77 & 0.72 & 0.96 & 0.82 \\
$\mathbf{N a}$ & -0.57 & -0.38 & 0.74 & 0.83 & 0.02 & 0.76 & 0.58 & 0.77 & 1 & 0.96 & 0.81 & 0.61 \\
$\mathbf{K}$ & -0.52 & -0.34 & 0.76 & 0.86 & 0.08 & 0.80 & 0.74 & 0.72 & 0.96 & 1 & 0.82 & 0.46 \\
$\mathbf{C E}$ & -0.86 & -0.77 & 0.98 & 0.88 & 0.29 & 0.98 & 0.83 & 0.96 & 0.81 & 0.82 & 1 & 0.75 \\
$\mathbf{p H}$ & -0.68 & -0.68 & 0.74 & 0.61 & 0.19 & 0.68 & 0.36 & 0.82 & 0.61 & 0.46 & 0.75 & 1 \\
\hline
\end{tabular}

Table 2: Establishment of the correlation matrix between the 12 variables and based on the 23 individuals. Note: TAC: complete alcalimetric title, DHT: Tolerable weekly dose, CE: Electrical conductivity.

\begin{tabular}{|llllllllllll|}
\hline Parameter & $\begin{array}{l}\mathbf{H C O}_{3} \\
(\mathbf{m g l})\end{array}$ & $\begin{array}{l}\mathbf{C l} \\
(\mathbf{m g l})\end{array}$ & $\begin{array}{l}\mathrm{SO}_{4} \\
(\mathbf{m g l})\end{array}$ & $\begin{array}{l}\mathbf{N O}_{3} \\
(\mathbf{m g l})\end{array}$ & $\begin{array}{l}\text { DHT } \\
(\mathbf{m e q})\end{array}$ & $\begin{array}{l}\mathbf{C a} \\
(\mathbf{m g l})\end{array}$ & $\begin{array}{l}\mathbf{M g} \\
(\mathbf{m g l})\end{array}$ & $\begin{array}{l}\mathbf{N a} \\
(\mathbf{m g l})\end{array}$ & $\begin{array}{l}\mathbf{K} \\
(\mathbf{m g l})\end{array}$ & $\begin{array}{l}\mathbf{C E} \\
\mathbf{m s} / \mathbf{c m}\end{array}$ & $\mathbf{P H}$ \\
\hline $\mathbf{P 1}$ & 201.3 & 106.5 & 15 & 40 & 6.6 & 122.23 & 11.76 & 23.46 & 0.065 & 0.77 & 6.3 \\
$\mathbf{P 2}$ & 274.5 & 134.9 & 250 & 3.7 & 10 & 160.32 & 23.76 & 80.73 & 0.715 & 1.28 & 6.5 \\
$\mathbf{P 3}$ & 100.04 & 495.25 & 380 & 43 & 20.6 & 200.4 & 126.95 & 106.95 & 0.825 & 3.17 & 8.4 \\
$\mathbf{P 4}$ & 201.3 & 266.25 & 120 & 65 & 10.4 & 164.39 & 26.16 & 66.7 & 0.533 & 1.62 & 7.1 \\
$\mathbf{P 5}$ & 176.9 & 330.1 & 300 & 60 & 17 & 244.49 & 57.24 & 44.37 & 0.477 & 2.17 & 6.9 \\
$\mathbf{P 6}$ & 246.44 & 60.35 & 135 & 52 & 7.2 & 120.24 & 14.16 & 35.88 & 0.093 & 0.84 & 7.2 \\
P7 & 211.06 & 152.65 & 125 & 4.3 & 8.8 & 125.86 & 30 & 31.52 & 0.084 & 1.12 & 7.2 \\
P8 & 201 & 99 & 15 & 35 & 6 & 120.3 & 10 & 21.8 & 0.059 & 0.8 & 6.4 \\
P9 & 210 & 130.3 & 14 & 34 & 6 & 120.8 & 12.7 & 20.5 & 0.063 & 0.82 & 7.1 \\
\hline
\end{tabular}

Table 3. Average values of the physicochemical parameters of each well analyzed.

- an inverse relation between $\mathrm{HCO} 3-$ and $\mathrm{Mg} 2+$, indicating the possibility that the water crosses the two geological formations (halite and carbonates);

- a good correlation of $\mathrm{Mg}+$ and $\mathrm{Cl}$ - with salinity and conductivity.

The average values of the physicochemical parameters of each well are presented in Table 3.

Figures 2 and 3 show that the highest values are that of $\mathrm{Ca}++, \mathrm{NO} 3$ and $\mathrm{Cl}-$, which exceed the standards of Algerian potability.

The variations of dissolved salts make it possible to distinguish the two sources of salinization from water (Table 3). The waters of wells P3 and
P5, with very high levels of chloride and notable sodium, are contaminated by salt lake.

Except for the wells P1, P8 and P9, the rest of the waters indicate a high contamination by the salts of the evaporites, in particular the wells P3 and P5, with considerable contents of sulphates and calcium.

Calcium, magnesium and sodium are the most common cations in surface and groundwater. They depend mainly on the geology (deposits of carbonates or gypsum present, etc.).

Nitrates are important to follow. Indeed, found in excess, they are an indisputable marker of pollution. At the level of the studied waters, the average concentration of nitrates is of the order of $35 \mathrm{mg} / 1$ 
which complies with the norm of $50 \mathrm{mg} / \mathrm{l}$ fixed by the WHO (O.M.S, 1986), in terms of potability.

High values were recorded in the center of the plain. This deterioration of the quality of these three wells (P4, P5 and P6) by nitrates could be attributed to point and dispersal releases of livestock products and the use of chemical fertilizers and pesticides related to agricultural activities, which then infiltrated through the soil to the water table. Although nitrates have no direct toxic effects except at high doses, they are readily converted by bacterial reduction into nitrites, the health effects of which would not be neutral (Elbouqdaoui et al., 2009).

\section{Principal component analysis (APC)}

The projection of the 12 variables and 23 individuals, by principal component analysis, on axes 1 and 2 is presented in the three figures 4, 5 and 6 .

The projection of the variables shows that the axis 1 presents the salinity with two poles:

-The first proportional to salinity: it is presented by the proportional correlations between $\mathrm{Mg}+$ and $\mathrm{Cl}$; NO3, EC, SO4, Na, K and pH; salinity, conductivity and $\mathrm{Ca} 2+$. Indicating that the salinity of waters is related to both the dissolution of $\mathrm{MgCl} 2$ and $(\mathrm{NaCl})$ and the gypsum formations (CaSO4).

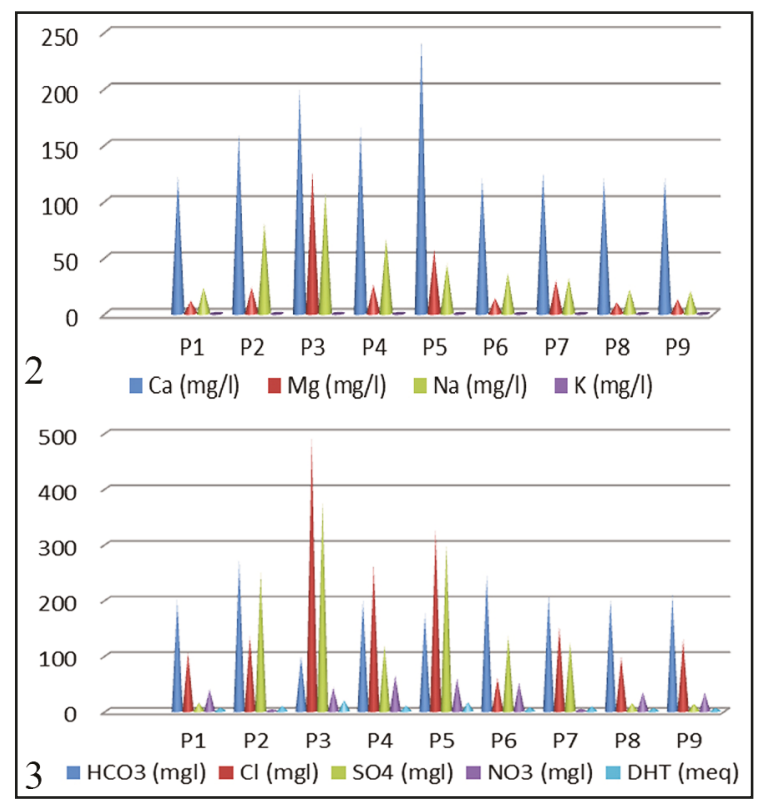

Figures 2, 3. Physicochemical parameters of irrigation wells of cations (Fig. 2) and anions (Fig. 3).
Ca2+ and SO4-2 have strong relations, and it can be related to the fact that the calcium comes at the same time from the dissolution of the limestones and the gypsum.

The projection of the individuals shows that this salinity is mainly linked to the wells P3, P4 and P5 by $\mathrm{MgCl} 2$.

- The second has an inverse proportion to salinity and is represented by bicarbonates. The latter has an inverse relationship with nitrates.

Individuals with this cluster are: P2, P1, P6 and P7.

\section{Chemical facies of waters}

To determine the chemical facies of the water and its evolution over time, we used two diagrams: Piper diagram and Schoeler-Berkaloff diagram.

The Piper diagram (Fig. 7) shows the chemical facies of a set of water samples. It is composed of two triangles to represent the cationic facies and the anionic facies and a rhombus synthesizing the global facies. The principle consists in representing in each equilateral triangle the quantities in reaction with respect to the total concentration of the anions and the cations, one thus obtains two representative points indicating the dominance of an anion or a cation.

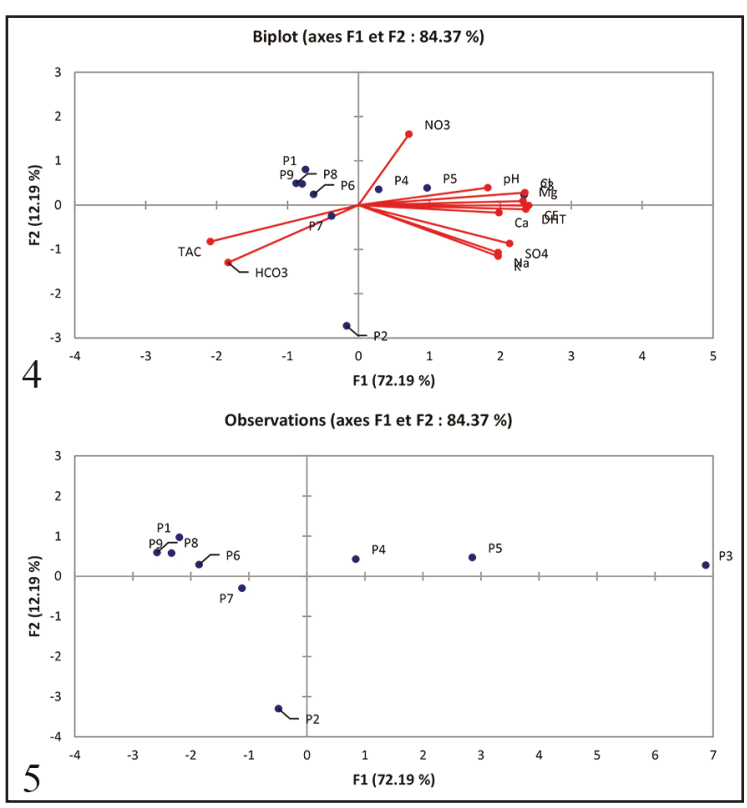

Figures 4, 5. Projection of Variables and Individuals on Axes 1 and 2 (APC). 


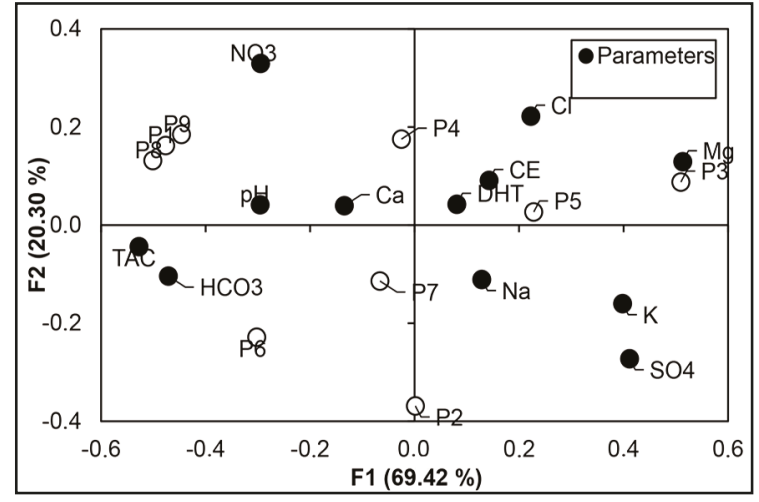

Figure 6. Symmetrical graph.

The composition of the water can be represented on the rhombus by a single point corresponding to the intersection of the parallels from these two points to the sides of the rhombus representing the chemical nature of the sample.

This diagram shows that the chemical facies of the waters is hyper-chlorinated calcium and hypersulphated calcium. Calcium hyperchloride facies is represented by the following wells: P3, P4, P5, P7, $\mathrm{P} 8$ and $\mathrm{P} 9$.

These diagrams show that the temporal evolution of the wells presents a gradual transition of water from sodium chlorides and potassium or sodium sulphated facies towards the hyperchloride sodium facies. This indicates an increase in chloride inputs Calcium of evaporitic origin (halite).

The Schoeller-Berkaloff diagram (Fig. 8) shows the chemical facies of several waters. Each sample is represented by a broken line. The concentration of each chemical element is represented by a vertical line in logarithmic scale. The broken line is formed by connecting all the points representing the different chemical elements. When the lines intersect, a chemical facies change is highlighted.

This diagram confirms that the most abundant ions are chlorine and calcium and sodium, and the least abundant chemical element is magnesium (Hillel, 1984).

The chemical quality of the water has a direct impact on farmland yield and soil conservation. For this purpose and given that the study area is agricultural, a chemical study of water for irrigation is essential to highlight the danger that certain chemical elements may present for plants and soils.
In order to appreciate the agricultural value of a solution, Wilcox (1949) proposed the first diagram delineating classes based on total mineralization and the percentage of sodium absorbed by water; then in 1954 the salinity laboratory of the US Department of Agriculture (Richards) proposed a second diagram also delineating classes based on total mineralization and sodium absorbed by soil (S.A.R).

The danger of alkalization is expressed by the value of the SAR, which is expressed as relation $\mathrm{N}^{\circ}$ 2:

$$
S A R=\sqrt{\frac{\mathrm{Ca}^{++}+\mathrm{Mg}^{+}}{2}}
$$

$\mathrm{Ca}++, \mathrm{Mg}++$ and $\mathrm{Na}+$ are expressed in (meq/l). This classification was proposed by Richards. It is very useful and reliable for characterizing irrigation water. Water loaded with salts can cause a risk for irrigation. This risk is determined using the Sodium Absorption Ratio (SAR) value. This parameter is a determination of the exchange capacity of $\mathrm{Ca} 2+$ ions, $\mathrm{Mg} 2+$, by $\mathrm{Na}+$ in clays and colloids.

The SAR does not take into account changes in the $\mathrm{Ca}++$ content of soil water occurring by precipitation or dissolution during or after irrigation. Sodium, which is an important factor in salinity, remains constantly soluble and in equilibrium with exchangeable sodium.

External agents have little influence on the dissolution or precipitation of sodium, whether it is concentrated by sampling the plant between two waterings, diluted by water applied or leached by drainage.

Sodium is an element of alkaline and alkaline earth bases. Given the heterogeneous nature of the soils, the relative proportions of $\mathrm{Ca}, \mathrm{Mg}, \mathrm{Na}$ are the main factors of the Sodium Adsorption Rate (SAR). If irrigated soils are supersaturated with sodium, the groundwater is contaminated by the effect of water return. Indeed, the cationic exchanges that take place in clays enrich the soils with salts (soils with crusts). This type of salinization affects semi-arid regions (Rodier, 1978).

Irrigation water quality is assessed using the U.S.S.L. Water Classification Chart (1954). It is a double-entry table, with the conductivities on the abscissa and the SAR on the ordinate. However, the 
proposed diagram was modified by the addition of a 5 th class based on electrical conductivity (Durand, 1958).

The report of the results on this diagram (Fig. 9) shows that the irrigation water of the F'Kirina plain belongs to class (C3S1). Generally, this class contains admissible water for the irrigation of crops tolerant to salts, on well-drained soils or good permeability and salinity should be controlled. Class C3S1 represents wells located northeast of the city of F'Kirina.

Generally, plants do not tolerate soils saturated with sodium. The Wilcox classification, based on electrical conductivity and sodium content in water, is expressed as a percentage. The representation of the different samples on this diagram allows the characterization of waters for their ability to irrigate (Fig. 10).

The representation of the different samples analyzed on the Wilcox diagram shows that the waters of the plains of the F'Kirina plain belong to the four classes; excellent, good, mediocre and bad.

The poor quality waters are located in the center

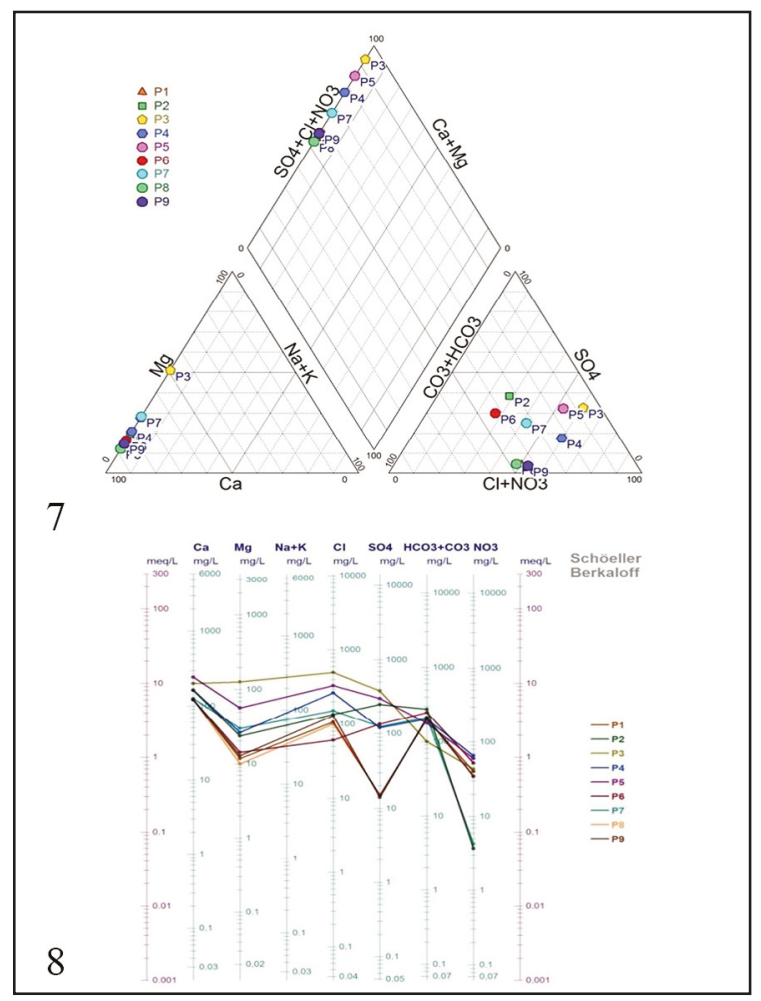

Figure 7. Representation of Piper Diagram in 2015. Figure 8. Schoeller-Berkaloff classification in 2015. of the plain (near the salt lake) where the conductivities are high, since the waters in this place are salty and charged (P3 and P5). To the south and east of the plain the waters are of acceptable quality, and on the rest of the ground the waters present a good quality.

\section{CONCLUSIONS}

In this study, we assessed the quality of groundwater used in irrigation in the F'Kirina plain and also defined the current situation of nitric pollution. This issue is of great importance because of the problems in the region due to drought, the unavailability of surface water and the high demand from agricultural activities.

The hydrochemical study of the waters of the plain of F'Kirina allowed us to highlight several observations:

- the presence of four chemical facies marking the heterogeneity of the lithology. In fact, we could mention the bicarbonated facies characterizing the

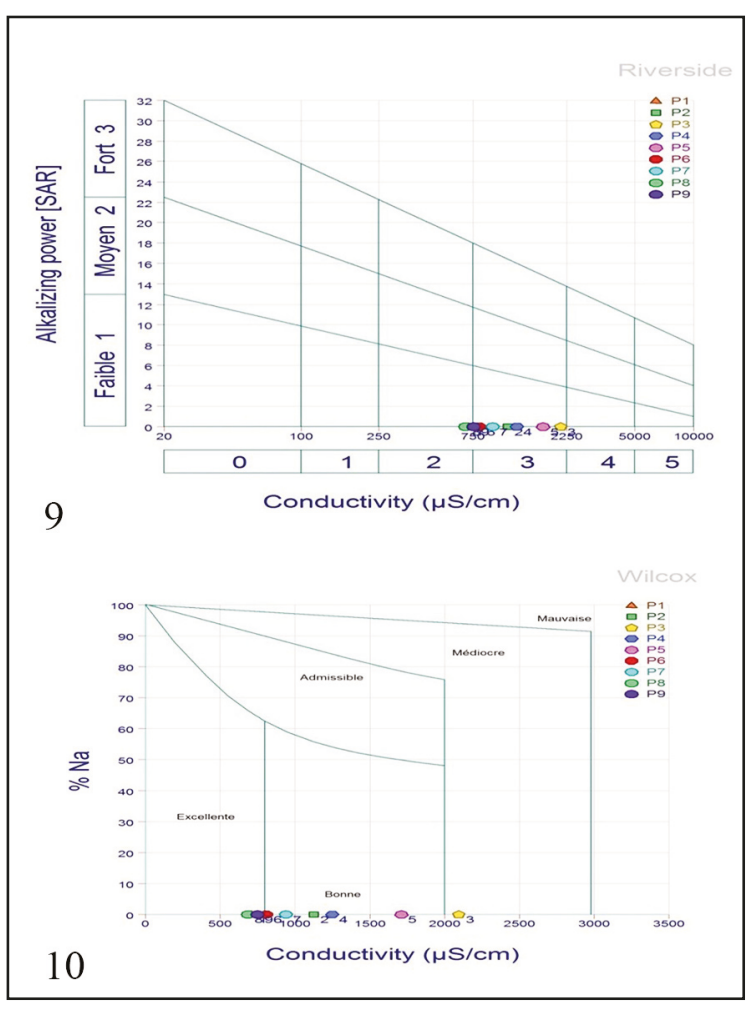

Figure 9. Water classification according to S.A.R. (2015). Figure 10. Idem, according to the percentage of $\mathrm{Na}$ (2015). 
water coming from the limestone margins, the chlorinated and sulphated facies resulting from the evaporitic formations and the salt facies, especially in the northern part of the aquifer;

- the spatial distribution of the chemical elements confirmed that the origin of these facies is strongly related to the lithological nature of the aquifer. The dissolution of carbonate and evaporitic formations is at the origin of this distribution.

The comparison of the concentrations of the chemical elements ( $\mathrm{Na}+, \mathrm{Cl}-, \mathrm{Ca} 2+, \mathrm{SO} 42-, \mathrm{HCO} 3)$ which characterize the main geological formations of the basin, highlighted the dominance of the salt ions $((\mathrm{Na}+, \mathrm{Cl}-)$ and the gypsiferous ions $(\mathrm{Ca} 2+$, SO42-) compared to those carbonates $(\mathrm{Ca} 2+$, HCO3-) in the acquisition of salinity.

Statistical analysis has shown that groundwater upstream of the aquifer is weakly mineralized and that downstream is highly mineralized.

The classifications of Richards and Wilcox showed the deterioration of water quality for irrigation.

In other words, there is much to confirm the existence of a significant contribution of intensive agricultural practices in the nitrate pollution of the groundwater of the plains of F'Kirina, and more particularly the nitrogen fertilization.

The choice of agronomic measures to combat nitric pollution of groundwater resources must be based on an assessment that compares, in terms of pollution reduction but also in terms of productivity, the measures envisaged. In addition, the control of groundwater pollution by nitrates could not be conceived without a program of sensitization of farmers and extension of adequate cultural practices to obtain good yields while respecting the nitric quality of groundwater resources.

The pollution of this groundwater with high doses of nitrates contained in its waters exposes the population of this region to the various types of intoxication that may result from the consumption of this water in the medium and long term. It is time that the public authorities and society as a whole act, so that we can take all the necessary steps to avoid an environmental catastrophe resulting in the deterioration of the health of the population. At the end of this study, we recommend:
- to install Hydrometric functional stations downstream of the plain near salt lake Gareat el Taref, to measure the liquid flows necessary for the determination of hydrological balance parameters;

- install piezometers near the boreholes in order to estimate the storage coefficient of the captured formations;

- control the use of fertilizers to avoid possible pollution by nitrates;

- reflection on the establishment of pollution vulnerability maps for the sensitivity of the aquifer of the studied region.

\section{REFERENCES}

Duran J.H., 1958. Les sols irrigables. Etude pédologique. Ed. Imbert, Alger, 190 pp.

Elbouqdaoui K., Aachib M., Blaghen M. \& Kholtei S., 2009. Modélisation de la pollution par les nitrates de la nappe de Berrechid, au Maroc, Afrique Sciences, 5: 99-113. http://10.4314/afsci.v5i1.61711

Hillel D., 1984. L'eau et le sol: principe et processus physiques. Vander édition. http://www.sudoc.fr/ 051218909

Id Ahmad F., 1998. Impact des activités agricoles et d'élevage sur la pollution nitrique des eaux souterraines dans le périmètre de Doukkala. Mém. 3ème Cycle.

O.M.S., 1986. Organisation Mondiale de la Santé "Charte d'Ottawa pour la promotion de la santé", Copenhagen: Bureau régional de l'Europe.

Mangin A., 1974. Contribution à l'étude hydrodynamique des aquifères karstiques. Concepts méthodologiques adoptés. Systèmes karstiques étudiés, Annales de Spéléologie, 29: 495-601.

Rodier J., 1978. L'analyse de l'eau: eaux naturelles, eaux résiduaires, eau de mer; chimie, physico-chimie, bactériologie, biologie. Dunod Technique, Paris, 1135 pp.; 913-919.

Soudi B., 1995. Problématique du compostage des déchets ménagers au Maroc: cas de Rabat-Salé, programme de la communauté européenne. Séminaire MED-URBS, Kénitra, 26-27.

Wilcox L.V., 1949. Water Quality From an Agricultural Point of View. Report of Interim Fact-finding Commission on Water Pollution, California State Assembly.

Zoller I., 1994. Non-ionic surfactants in reused water: are activated sludge/soil aquifer treatments sufficient. Water Research, 28: 1625-1629. 